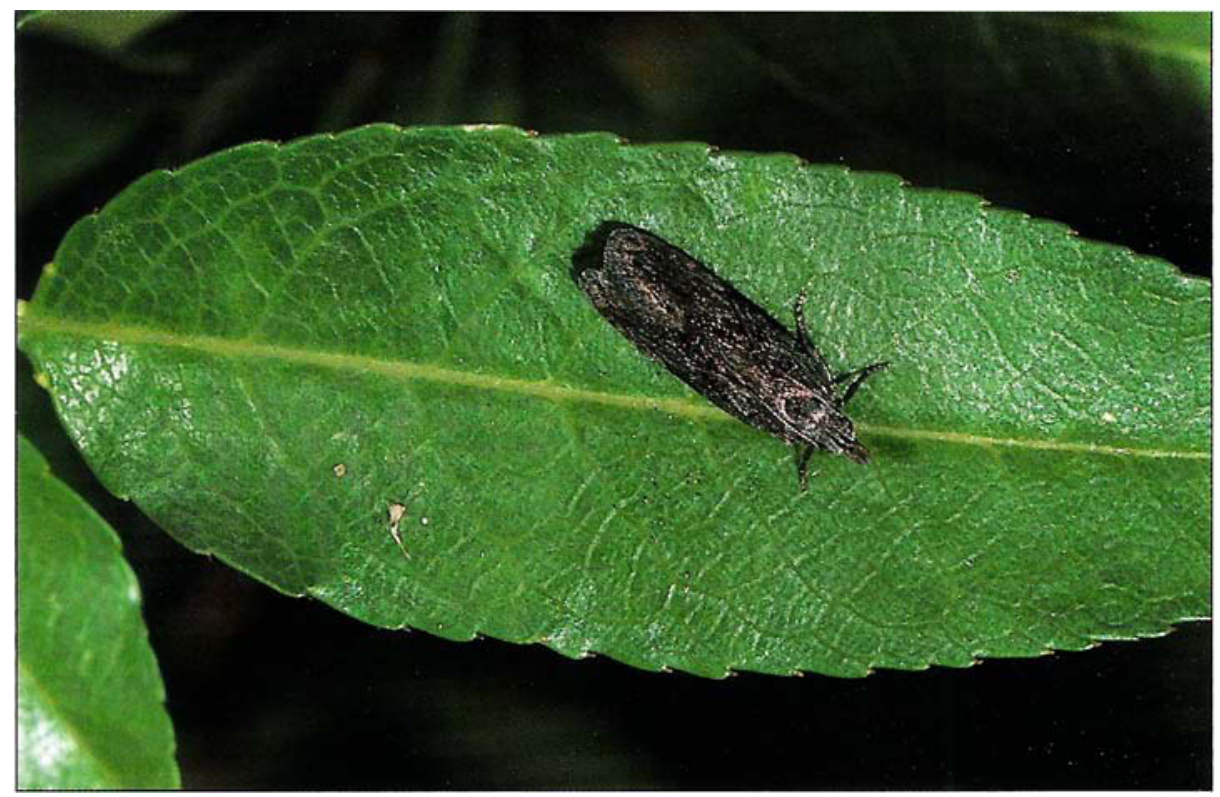

Adult peach twig borer moths often move into peach orchards from nearby prune or almond orchards late in the season. Although the larva (below) may injure shoot tips in the spring, the main concern is damage to ripening fruit.

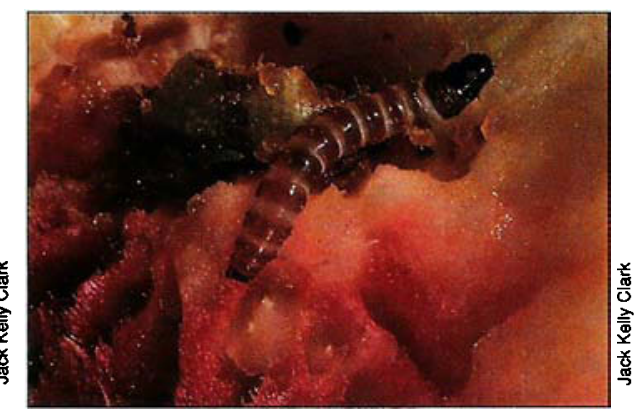

\title{
Distribution of peach twig borer damage in peaches
}

\author{
Craig V. Weakley $\square$ Philipp Kirsch $\square$ Frank G. Zalom
}

\section{Damage to fruit by the peach twig borer was greatest late in the sea- son and in the tops of trees at the orchard edges. Monitoring for damage should begin at least 4 weeks before harvest.}

The peach twig borer has been a major pest of California peaches for the past century. Before the introduction of the oriental fruit moth in the 1940s, peach twig borer was the most important lepidopterous pest of the crop, causing reported losses as high as $70 \%$.

Larvae of peach twig borer, Anarsia lineatella Zeller, damage both the shoot tips and the fruit. The insect has four generations per year in California. In the spring, overwintering and first generation larvae mine the succulent shoot tips, causing terminal dieback. If first generation population levels are high, some larvae may feed on the surface of green fruit, causing it to gum. During the two summer generations, the larvae shift feeding from the shoot tips to ripening fruit. They enter the fruit at the stem end, on the sides between two touching fruit, or along the suture. Feeding damage on fruit is usually very shallow, $1 /$ 8 to $1 / 4$ inch below the surface. Larger larvae may sometimes tunnel through the flesh to the pit.

Damage to the shoot tips in the spring can result in excessive lateral branching, which makes tree training difficult. The major economic concern, however, is damage that makes the fruit unsalable. Canners reject cling peach deliveries with "worm" damage in excess of $4 \%$ by weight because of the difficulty and expense of sorting damaged fruit. In the fresh market, peach lots with average worm damage greater than $5 \%$ exceed the U.S. No. 1 Grade Standard and cannot be marketed.

During the 1950s and 1960s, losses from peach twig borer were reduced by in-season insecticide sprays targeted for both twig borer and the oriental fruit moth, Grapholita molesta Busck. Since the early 1970s, a dormant-season spray of insecticide plus oil has replaced in-season sprays as the most effective strategy for peach twig borer control. Use of this dormant spray, combined with one or more in-season sprays for oriental fruit moth, virtually eliminated fruit damage caused by peach twig borer in many California peach orchards.

In 1987, commercial use of pheromone dispensers for control of oriental fruit moth by mating disruption began in California, replacing the in-season insecticide sprays. Because of the specificity of the pheromone dispensers, other insects including peach twig borer are not controlled. As a result, incidence of fruit damage by twig borer has increased. This damage occurs late in the season when the female peach twig borer moths move from nearby prune or almond orchards and lay eggs on ripening fruit in peach orchards containing pheromone dispensers.

During 1986, 1987, and 1988, we conducted field trials to determine the distribution of late-season fruit damage by peach twig borer in peach orchards. This report presents the results and describes a simple fruit-monitoring program. The program can be used by pest control advisers and growers to assess the potential for late-season peach twig borer damage in peach orchards containing oriental fruit moth pheromone dispensers.

\section{Field trials}

We conducted five field trials in three cling peach orchards in Sutter County and a freestone peach orchard in Yolo County (table 1). Each orchard received a dormant insecticide spray to control peach twig borer and two applications of pheromone dispensers to control oriental fruit moth. No in-season insecticide sprays were applied to these orchards before the final sampling date.

In the Rio Oso, Lomo, and Live Oak trials, fruit were sampled weekly beginning about 4 weeks before the predicted harvest date. Fruit were removed from trees and visually inspected for peach twig borer damage on each sampling date. Different trees were sampled each week. In the Winters trial, only one sample was taken at harvest.

The distribution of fruit damage in relation to tree quadrant and in edge versus 
center trees was recorded in all trial orchards. On each sampling date, 100 fruit were taken from the top (10 to 14 feet above the ground) of each tree sampled. Each 100fruit sample consisted of 25 randomly selected fruit from the north, south, east, and west tree quadrants. Five trees were sampled in the center of the orchard as well as five trees on the east, south, west, and north edges (north edge not sampled at Winters).

In three of the trials, an additional sample was taken to determine if the distance from an external peach twig borer source affected the distribution of fruit damage. This sample consisted of 100 fruit each from the tops of five trees in the first, third, fifth, seventh, and twelfth rows in from each source: a prune orchard at the north edge of the Live Oak orchard (1987 and 1988) and an almond orchard at the west edge of the Winters orchard (1988). In 1988, fruit were also sampled from the first, fifth, and twelfth rows in from the prune orchard adjacent to the east edge of the Live Oak orchard.

At Live Oak in 1988, an additional sample was taken to learn if the distribution of damage varies with the height of the fruit in the tree canopy. On each sampling date, 25 fruit per tree quadrant (100 fruit per tree) were taken from the lower half of the tree canopy ( 5 to 7 feet above the ground) on 25 trees. This sample was taken from the same 25 trees where top fruit were sampled in the edge versus center trees.

TABLE 1. Peach twig borer (PTB) trial locations, peach variety, sampling dates, and type of sample

Year,
orchard Variety Date Type

\begin{tabular}{|c|c|c|c|}
\hline $\begin{array}{l}\text { Rio Oso } \\
\text { (9 acres) }\end{array}$ & Klamt & $\begin{array}{l}\text { Jun } 26 \\
\text { Jul } 2 \\
\text { Jul } 9 \\
\text { Jul } 16\end{array}$ & $\begin{array}{l}\text { Edges vs. center } \\
\text { Tree quadrant }\end{array}$ \\
\hline
\end{tabular}

1987:

\begin{tabular}{|c|c|c|c|}
\hline $\begin{array}{l}\text { Lomo } \\
\text { (11.5 acres) }\end{array}$ & Corona & $\begin{array}{l}\text { Jul } 31 \\
\text { Aug } 7 \\
\text { Aug } 14 \\
\text { Aug } 28\end{array}$ & $\begin{array}{l}\text { Edges vs. center } \\
\text { Tree quadrant }\end{array}$ \\
\hline $\begin{array}{l}\text { ve Oak } \\
\text { acres) }\end{array}$ & Corona & $\begin{array}{l}\text { Jul } 27 \\
\text { Aug } 3 \\
\text { Aug } 10\end{array}$ & $\begin{array}{l}\text { Edges vs. center } \\
\text { Tree quadrant } \\
\text { Distance from } \\
\text { PTB source }\end{array}$ \\
\hline
\end{tabular}

1988:

$\begin{array}{cll}\text { Live Oak } & \text { Corona } & \text { Aug 3 } \\ \text { (9 acres) } & \text { Aug 12 } & \begin{array}{l}\text { Edges vs. center } \\ \text { Tree quadrant } \\ \text { Distance from } \\ \text { PTB source } \\ \text { Fruit height }\end{array} \\ & & \text { Fing }\end{array}$

Winters Fay Aug 11 Edges vs. center (5 acres) Elberta Treequadrant Distance from PTB source

\section{Results}

Sampling date. Fruit damage increased with each sampling date at all locations (table 2). Damage at harvest was significantly greater than at earlier sampling dates at Rio Oso, Lomo, and at Live Oak in 1988.

Sampling location. The amount of fruit damage was greater in trees at an orchard edge than in those in the center in all trials (table 3). Fruit damage was significantly greater on the southern edge of the orchard than on all other sampling locations at Rio Oso, Lomo, and Winters.

Distance from source. In general, fruit damage decreased with increasing distance from the external peach twig borer source (table 4). Fruit damage in the edge row (row 1) closest to the external source (prunes or almonds) was significantly greater than damage in rows farther from the source at Live Oak in 1987, Live Oak in 1988 (both the north and east edges), and Winters.

Tree quadrant. Although no strong conclusion can be drawn from the data, fruit damage tended to be greater in the southern and eastern tree quadrants (table 5).

Sampling height. Fruit damage was significantly greater $(p<0.0001)$ at the top of trees than in the lower half of tree canopies. Average damage per 100 fruit from the top was 5.80 \pm 6.61 (mean \pm S.D.) compared with $0.80 \pm 2.28$ (mean \pm S.D.) from the lower half.

\section{Discussion}

In these field trials, the distribution of damage by peach twig borer to fruit was not random within orchards or within trees. Fruit damage was greatest on the last sampling date and was concentrated in the tops of trees in rows on the orchard edges.

One possible explanation for fruit damage being.greatest on the last sampling date is that peach twig borer egg-laying activity was increasing during the sampling period. Table 6 shows the sampling dates for each orchard and the corresponding degree-day accumulations $\left({ }^{\circ} \mathrm{F}\right)$ for the coinciding peach twig borer generation. Egg hatch begins after 220 degree-days have accumulated, and no eggs are laid after about 800 degreedays.

The degree-day accumulations indicate that the increase in fruit damage with time could be explained by a coinciding increase in egg-laying in the 1987 and 1988 orchards. At Rio Oso, however, the degree-day accumulations indicate that fruit damage should have peaked on July 9. But damage on July 16 was significantly greater. This increase occurred after the predicted period of egg-laying for second generation eggs. In addition, at Lomo (July 31) and Live Oak in 1987 (July 27 and Aug. 3) fruit damage was found before the predicted start of egg-laying (220 degree-days) for the third genera- tion. These observations support previous reports that peach twig borer egg-laying overlaps during the summer generations. Because of this egg-laying overlap, an increase in twig borer egg laying cannot be the sole explanation for finding the greatest damage on the last sampling date.

A second possible explanation for damage being greatest on the last sampling date is

\begin{tabular}{|c|c|c|}
\hline $\begin{array}{l}\text { Year, } \\
\text { orchard }\end{array}$ & $\begin{array}{l}\text { Sampling } \\
\text { date }\end{array}$ & Frult damaged* \\
\hline $\begin{array}{l}\text { 1986: } \\
\text { Rio Oso }\end{array}$ & $\begin{array}{l}\text { Jun } 26 \\
\text { Jul } 2 \\
\text { Jul } 9 \\
\text { Jul } 16\end{array}$ & $\begin{array}{l}0.040 \pm 0.400 b \\
0.160 \pm 0.800 b \\
0.200 \pm 0.880 b \\
0.880 \pm 2.320 a\end{array}$ \\
\hline
\end{tabular}

1987:

Lomo

Jul $31 \quad 0.006 \pm 0.008 b$

Aug $7 \quad 0.005 \pm 0.007 b$

Aug $14 \quad 0.007 \pm 0.011 \mathrm{~b}$

Aug $28 \quad 0.019 \pm 0.030 \mathrm{a}$

Live Oak Jul $27 \quad 0.014 \pm 0.141 \mathrm{a}$

Aug $3 \quad 0.018 \pm 0.021 \mathrm{a}$

Aug $10 \quad 0.022 \pm 0.021 \mathrm{a}$

1988:

Live Oak Aug $3 \quad 3.280 \pm 5.668 b$

Aug $12 \quad 7.080 \pm 6.378 \mathrm{a}$

- Means ( \pm standard deviation) within year followed by the same letter are not significantly different $(P<0.05)$; Duncan's (1955) multiple range test.

TABLE 3. Fruit damaged by peach twig borer per 100-fruit sample (edges vs. center samples)

\begin{tabular}{lll}
\hline $\begin{array}{l}\text { Year, } \\
\text { orchard }\end{array}$ & Location & Fruit damaged* \\
\hline 1986: & & \\
Rio Oso & South edge & $0.920 \pm 2.480 \mathrm{a}$ \\
& West edge & $0.400 \pm 1.200 \mathrm{~b}$ \\
& East edge & $0.200 \pm 0.880 \mathrm{~b}$ \\
& North edge & $0.040 \pm 0.440 \mathrm{~b}$ \\
& Center & $0.040 \pm 0.440 \mathrm{~b}$
\end{tabular}

1987:

Lomo

South edge

$0.022 \pm 0.032 a$

North edge

West edge

East edge

$0.009 \pm 0.011 b$

Center

$0.007 \pm 0.009 \mathrm{~b}$

$0.005 \pm 0.008 b$

$0.004 \pm 0.010 b$ North edge $\quad 0.039 \pm 0.031 \mathrm{a}$ South edge $\quad 0.030 \pm 0.027 \mathrm{ab}$ West edge $\quad 0.029 \pm 0.021 \mathrm{ab}$ Center $\quad 0.013 \pm 0.018 b$

1988:

Live Oak North edge $\quad 7.600 \pm 6.392$ a West edge $\quad 5.800 \pm 8.200 \mathrm{ab}$ South edge $\quad 5.100 \pm 5.358 \mathrm{ab}$ East edge $\quad 4.700 \pm 6.001 \mathrm{bc}$ $\begin{array}{ll}\text { Center } & 2.700 \pm 4.189 \mathrm{C}\end{array}$

$\begin{array}{clr}\text { Winters } & \text { South edge } & 25.60 \pm 2.970 \mathrm{a} \\ & \text { East edge } & 15.60 \pm 3.290 \mathrm{~b} \\ & \text { West edge } & 14.00 \pm 7.940 \mathrm{~b} \\ & \text { Center } & 6.80 \pm 1.780 \mathrm{C}\end{array}$

- See footnote ("), table 2. 
that peach twig borer females prefer to lay eggs on the most mature fruit in the orchard. Fruit damage also was greatest in the tops of trees where fruit mature earliest. In three of five trials, fruit damage was greatest in trees on the orchard's southern edge, which has the most exposure to sun and where fruit are likely to be more mature than on the other edges. There was also a

\begin{tabular}{|c|c|c|c|}
\hline $\begin{array}{l}\text { Year, } \\
\text { orchard }\end{array}$ & Edge & Distance & Fruit damaged ${ }^{\star}$ \\
\hline \multicolumn{4}{|c|}{ row } \\
\hline $\begin{array}{l}\text { 1987: } \\
\text { Live Oak }\end{array}$ & North & $\begin{array}{r}1 \\
3 \\
5 \\
7 \\
12\end{array}$ & $\begin{array}{l}0.035 \pm 0.026 a \\
0.017 \pm 0.015 b \\
0.014 \pm 0.015 b \\
0.014 \pm 0.011 b \\
0.009 \pm 0.015 b\end{array}$ \\
\hline $\begin{array}{l}\text { 1988: } \\
\text { Live Oak }\end{array}$ & North & $\begin{array}{r}1 \\
5 \\
7 \\
3 \\
12\end{array}$ & $\begin{array}{l}7.600 \pm 6.392 a \\
4.100 \pm 4.834 b \\
4.100 \pm 5.834 b \\
3.700 \pm 5.155 b \\
2.700 \pm 4.189 b\end{array}$ \\
\hline Live Oak & East & $\begin{array}{r}1 \\
5 \\
12\end{array}$ & $\begin{array}{l}4.700 \pm 6.000 a \\
1.200 \pm 2.256 b \\
0.500 \pm 1.616 b\end{array}$ \\
\hline Live Oak & $\begin{array}{l}\text { North } \\
\text { and east } \\
\text { combined }\end{array}$ & $\begin{array}{r}1 \\
7 \\
3 \\
5 \\
12\end{array}$ & $\begin{array}{l}6.150 \pm 6.332 a \\
4.100 \pm 5.836 b \\
3.700 \pm 5.156 b \\
2.650 \pm 4.024 b \\
1.600 \pm 3.344 c\end{array}$ \\
\hline Winters & West & $\begin{array}{r}1 \\
3 \\
5 \\
7 \\
12\end{array}$ & $\begin{array}{r}21.20 \pm 1.790 a \\
10.00 \pm 5.100 b \\
8.80 \pm 3.030 b \\
6.80 \pm 3.030 b \\
6.80 \pm 1.790 b\end{array}$ \\
\hline
\end{tabular}

- See footnote ("), table 2.

TABLE 5. Fruit damaged by peach twig borer per 100-frult sample in each tree quadrant

\begin{tabular}{lll}
\hline $\begin{array}{l}\text { Year, } \\
\text { orchard }\end{array}$ & Quadrant & Frult damaged* \\
\hline 1986: & & \\
Rio Oso & South & $0.440 \pm 1.960 \mathrm{a}$ \\
& East & $0.440 \pm 1.400 \mathrm{a}$ \\
& West & $0.320 \pm 1.080 \mathrm{ab}$ \\
& North & $0.080 \pm 0.560 \mathrm{~b}$ \\
& & \\
1987: & South & $0.013 \pm 0.027 \mathrm{a}$ \\
Lomo & East & $0.009 \pm 0.028 \mathrm{a}$ \\
& West & $0.008 \pm 0.021 \mathrm{a}$ \\
& North & $0.008 \pm 0.019 \mathrm{a}$ \\
& & \\
Live Oak & North & $0.088 \pm 0.148 \mathrm{a}$ \\
& West & $0.088 \pm 0.124 \mathrm{a}$ \\
& East & $0.072 \pm 0.136 \mathrm{ab}$ \\
& South & $0.036 \pm 0.084 \mathrm{~b}$ \\
1988: & & \\
Live Oak & South & $7.040 \pm 8.064 \mathrm{a}$ \\
& East & $5.680 \pm 6.368 \mathrm{ab}$ \\
& North & $4.240 \pm 5.137 \mathrm{~b}$ \\
& West & $3.760 \pm 4.809 \mathrm{~b}$ \\
\hline
\end{tabular}

* See footnote $\left({ }^{\star}\right)$, table 2. slight tendency for greater fruit damage to occur on the southern tree quadrant.

We also found that trees in edge rows had the most fruit damage and that the damage decreased with distance from an external source of peach twig borer. This damage was probably due to migration of female moths from external sources such as almonds or prunes, which are common sources of peach twig borer late in the season. This observed edge damage has implications for control of peach twig borer late in the season. In orchards such as Live Oak in 1987, where overall fruit damage is low, damage in the center of the orchard would not be of economic concern. But economic damage in the rows near the edges of such orchards could be prevented with an insecticide spray applied only to those rows. In orchards such as Winters, where overall fruit damage is high, damage in the center would be of economic concern, and the entire orchard would probably require treatment.

Our trial orchards were bordered by various combinations of peach twig borer sources (almonds, apricots, peaches, and prunes) and nonsources (walnuts, open fields, and drying yards). Although assessing the relative importance of these outside sources was not a primary objective of this study, our observations suggest that the nature and location of the outside source affects the distribution of fruit damage. This was apparent at Live Oak in 1987 and 1988. Migration of peach twig borer from mature prune orchards on the north (not dormantsprayed) and on the east resulted in greater fruit damage on the northern and eastern edges than on the southern edge in 1987 and in greater fruit damage on the northern edge than on the southern edge in 1988 .

TABLE 6. Sampling dates, peach twig borer generation, and degree-day accumulations for trial orchards

\begin{tabular}{llcc}
\hline $\begin{array}{l}\text { Year, } \\
\text { orchard }\end{array}$ & Date & Generation & $\begin{array}{c}\text { Accumulated } \\
\text { degree-days }\end{array}$ \\
\hline 1986: & & & \\
Rio Oso & Jun 26 & 2 & 455 \\
& Jul 2 & 2 & 616 \\
& Jul 9 & 2 & 796 \\
& Jul 16 & 2 & 981 \\
1987: & & & \\
Lomo & Jul 31 & 3 & 113 \\
& Aug 7 & 3 & 315 \\
& Aug 14 & 3 & 482 \\
& Aug 28 & 3 & 785 \\
Live Oak & Jul 27 & 3 & 27 \\
& Aug 3 & 3 & 196 \\
& Aug 10 & 3 & 392 \\
1988: & & & \\
Live Oak & Aug 3 & 3 & 333 \\
& Aug 12 & 3 & 554 \\
Winters & Aug 11 & 3 & 776 \\
\hline
\end{tabular}

Fruit damage was also significantly greater on the northern quadrant than on the southern quadrant in 1987. Migration from the concentrated peach twig borer sources on the northern and eastern borders may have overwhelmed the insect's tendency to favor southern tree rows as seen in other trial orchards.

\section{Monitoring guidelines}

An understanding of the distribution of peach twig borer damage can be used in a simple fruit monitoring program for peach orchards where in-season insecticide sprays do not protect the fruit from late-season damage. Peach orchards adjacent to almonds, prunes, and other stone fruits are particularly vulnerable to peach twig borer migration. Individual orchards must be monitored separately, because the insect's population density varies widely between locations.

Fruit monitoring, at least once a week, should begin at least 4 weeks before the expected harvest date. Fruit samples should be taken from the tops of trees, from the southern edge row, and from edge rows adjacent to external sources of peach twig borer. Until additional research is conducted to determine appropriate sample sizes, we suggest that at least 25 fruit per tree and at least four trees per edge row be sampled on each sampling date.

A few growers and pest control advisers successfully monitored peach twig borer damage to fruit using these guidelines during the 1988 season. Where low levels of fruit damage were detected, such as Live Oak in 1987, a border spray covering five exterior tree rows (100 feet wide) on all edges of the orchard gave good control when applied soon after larvae were found entering fruit. Where high levels of damage were detected, as at Live Oak in 1988 and Winters, a full cover spray should have been applied as soon as larvae were found.

Fruit monitoring programs, such as the one suggested here for peach twig borer damage, will become increasingly important as peach growers move from use of broad-spectrum insecticides toward selective insect control methods.

Craig V. Weakley was formerly Farm Advisor, University of California Cooperative Extension, Sutter-Yuba counties; Philipp Kirsch is Field Development Manager, North America, Biocontrol Ltd., Davis; Frank G. Zalom is Extension Integrated Pest Management Specialist, UC Davis. The authors thank growers C. Johnson, W. Filter Jr., J. Micheli, and D. Norene; Pest Control Adviser G. Post; Field Assistants $D$. Havens and P. Thunen; and Farm Advisor I. Studdert for their assistance. This research was supported in part by the California Cling Peach Advisory Board. 